\title{
Training on Developing Children's Social Character Through Sundanese Cultural Values
}

\author{
Eldi Mulyana ${ }^{1}$, Ade Suherman ${ }^{2}$, Triani Widyanti ${ }^{3}$, Tetep ${ }^{4}$, Asep Supriyatna ${ }^{5}$, Fadlika Sulaeman ${ }^{6}$, \\ Hilmi $^{7}$, Nurdin Miptahul Ulum ${ }^{8}$, Irwan Nurkholis ${ }^{9}$, Nia Kurniawan ${ }^{10}$ \\ Program Studi Pendidikan IPS Fakultas PISBS IPI Garut \\ *Email: eldimulyana@institutpendidikan.ac.id
}

\begin{abstract}
The purpose of this service is to provide counseling and training for residents in Sukamanah Village, Cigalontang District, Tasikmalaya Regency, West Java Province, to develop children's social character through Sundanese cultural values. The method used is to give lectures related to the theory and continued with parenting training through Sundanese cultural values. The results of the evaluation of this activity can be concluded that there is an increase in knowledge, attitudes and skills about parenting through the value of Sundanese culture to develop the social character of children. All community members in the area are very enthusiastic and understand about methods to develop children's social character through Sundanese cultural values after undergoing counseling and training. Counseling and training is carried out well because the majority of people in the place are Sundanese so they can easily apply what they have been trained.
\end{abstract}

Keywords: Children's Social Character, Parenting Parents, Sundanese Cultural Values.

\begin{abstract}
Abstrak
Tujuan pengabdian ini adalah memberikan penyuluhan dan pelatihan warga di Desa Sukamanah Kecamatan Cigalontang Tasikmalaya Jawa Barat untuk mengembangkan karakter sosial anak melalui nilai budaya sunda. Metode yang dilakukan adalah dengan memberikan penyuluhan secara ceramah berkaitan dengan teori dan dilanjutkan dengan pelatihan pola asuh orang tua melalui nilai budaya sunda. Hasil evaluasi kegiatan ini dapat disimpulkan bahwa ada peningkatan pengetahuan, sikap dan keterampilan tentang pola asuh orang tua melalui nilai budaya sunda untuk mengembangkan karakter sosial anak. Semua warga masyarakat di daerah tersebut sangat antusias dan faham mengenai metode mengembangkan karakter sosial anak melalui nilai budaya sunda setelah mengalami penyuluhan dan pelatihan. Penyuluhan dan pelatihan dilaksanakan dengan baik karena mayoritas di tempat tersebut suku sunda sehingga dapat dengan mudah mengaplikasikan apa yang telah dilatihkan.
\end{abstract}

Kata Kunci: Karakter Sosial Anak, Pola Asuh Orang tua, Nilai Budaya Sunda.

\section{Article Info:}

Received 09 April 2020

Accepted 15 April 2020

Available online 31 Agustus 2020

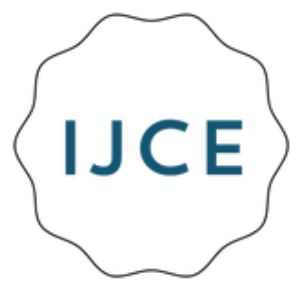




\section{PENDAHULUAN}

Suku Sunda mayoritas berdomisili di Provinsi Jawa Barat dan merupakan etnis terbesar di Indonesia. Sebagai suku terpadat kedua, Sunda yang memiliki ciri khas dari karakter orangnya, kulturnya, wilayahnya, dialektikanya sudah lama memberikan sumbangsih terhadap perjuangan bangsa dan negara. Arus globalisasi di Era Revolusi Industri 4.0 telah merubah dan menggeser sedikit demi sedikit paradigma masyarakat. Hal tersebut ditandai dengan kemudahan masyarakat dalam mendapatkan informasi dari luar yang mereka konsumsi begitu saja dalam kehidupan sehari-hari. Widyanti, Tetep dan Mulyana (2019) mengemukakan bahwa tidak jarang pengaruh negatif muncul dari pengaruh perkembangan revolusi tersebut tanpa kecuali menggeser norma dan tataran nilai budaya Sunda itu sendiri pada masyarakat Jawa Barat. Tidak bisa dipungkiri peran orang tua menjadi sangat penting sebagai penerus dalam hal pewarisan budaya Sunda kepada anaknya sebagai generasi penerus. Anak-anak perlu dididik karakter sosialnya agar tumbuh dan melekat rasa cinta terhadap budaya leluhurnya dengan mengimplementasika nilai budaya Sunda di dalamnya.

Tentu saja kita tidak antipati terhadap perkembangan zaman. Namun, sangatlah penting pewarisan nilai budaya Sunda diajarkan pada anak sebagai karakter sosial bagi mereka dengan pola asuh orang tua didalamnya. Peran orang tua menjadi sangat penting dalam pewarisan nilai budaya Sunda ini mengingat anak masa kini lebih senang menggandrungi seni budaya dari luar Indonesia. Tayangan televisi dan media sosial lebih banyak porsinya menayangkan kultur budaya asing nan kontemporer dibandingkan budaya dalam negeri (Mulyana, Tetep, \& Widyanti, 2018). Apalagi ditambah nilai budaya Sunda jarang sekali ditampilkan dalam acara televisi maupun media sosial yang sehari-hari dapat diakses dengan mudah oleh anak. Pola asuh orang tua menjadi pemeran penting dalam menumbuhkan kembali karakter sosial anak agar nilai budaya Sunda sebagai warisan nenek moyang tidak hanya tinggal cerita dahulu kala berupa dongengan semata.

Hal ini dalam versi ilmu pengetahuan sosial (IPS) terdapat dua persoalan yang dihadapi seperti dalam perspektif secara emik dan secara etik. Misal, secara emik bahwa masyarakat Sunda itu sendiri sebagai pemegang otoritas kebudayaannya terus-menerus melakukan seleksi alam terhadap unsur kebudayaan sehingga bisa diklasifikasikan mana yang wajib dipertahankan dan mana yang mengalami perubahan atau mungkin bisa saja ditinggalkan dan dianggap tidak relevan dengan perkembangan zaman (JD Narwoko, 2007). Bila ditinjau secara etik, maka Lembaga Swadaya Masyarakat (LSM) bahkan negara sangat diperlukan perannya dalam merekayasa bagaimana caranya untuk menggerakan perubahan yang terjadi dengan menyisipkan nilai-nilai khas budaya Sunda itu sendiri. Misalnya, dengan mengadakan seminar dan lokakarya, artikel-artikel berbahasa Sunda dan disebar ke media sosial, atau membuat konten video-video yang menarik sebagai jembatan pengenalan kepada anak yang tanpa disadarinya merupakan sebuah proses pewarisan nilai leluhurnya.

Budaya Sunda dianggap sebagai budaya yang hidup dan tumbuh di masyarakat Sunda itu sendiri yang mayoritas berdomisili di Provinsi Jawa Barat. Budaya ini memiliki sistem kepercayaan yang dianut, adat istiadat yang kental dengan sejarah dan simboliknya, mata pencaharian yang khas suku Sunda dalam bercocok tanam dan metode yang digunakannya, bahkan kesenian yang memiliki ciri khas tersendiri dan dianggap sakral pada saat melakukannya dan dimulai dari saat mempelajarinya dengan berbagai pepatah yang diajarkan sang juru latih walaupun unsur teknologi sudah masuk didalamnya. Budaya Sunda memiliki sistem sosial yang turun temurun diajarkan kepada anaknya sebagai garis pewaris keturunan di mana nilai-nilai khas sangat dihormati dan sakral pada saat melaksanakannya. Hal tersebut tercermin dalam pameo seperti silih asah, silih asih dan silih asuh. Silih asah artinya kita sebagai orang Sunda harus saling melindungi satu sama lainnya. Sementara itu, silih asih memiliki makna saling mengasihi sesama suku Sunda. Terakhir pameo silih asuh memiliki makna saling 
memperbaiki diri dengan konsep saling mengingatkan di dalamnya. Selain itu, nilai kesopanan menjadi ciri khas tersendiri pada budaya Sunda dan dianggap sangat bernilai di mana rasa menghormati orang tua, sayang terhadap yang lebih kecil, menghormati tamu dan rendah hati terhadap sesama menjadi metode yang diajarkan turun temurun. Ciri khas yang kental adalah sistem gotong royong tanpa disuruh tetapi atas kemauan sendiri yang muncul dengan contoh nenek moyangnya dahulu di mana saling membantu ketika orang lain memerlukan pertolongan atau ada acara tertentu.

Masa kini budaya Sunda sedikit demi sedikit mengalami pergeseran akibat arus globalisasi yang datang ke tanah air. Tidak dapat dipungkiri bahwa nilai-nilai budaya Sunda banyak ditinggalkan oleh orang tua dan terkesan bangga ketika berbicara dalam bahasa asing yang bukan dari kulturnya. Bukannya tidak boleh melakukan hal demikian akan tetapi ciri khas budaya Sunda sebagai identitas tetap wajib harus diwariskan kepada generasi muda. Globalisasi budaya yang terjadi saat ini menjadi fenomena di seluruh dunia dan melebur menjadi satu sebagai bentuk kolaborasi. Arjun Appadurai (dalam Anastasya, 2011 hlm. 12) seorang antropolog asal India mengemukakan bahwa pergerakan globalisasi budaya terdiri dari ethnoscape, mediascape, technoscape, finanscape, dan ideoscape. Kelima pergerakan globalisasi budaya tersebut memiliki aspeknya tersendiri seperti Ethnoscape yang merupakan ruang bagi pergerakan manusia itu sendiri, baik imigran atau turis bahkan para pengungsi pun termasuk. Sementara itu, mediascape lebih ke media sosial yang sehari-hari dikonsumsi masyarakat sebagai literasi informasi seperti televisi, koran, majalah bahkan internet (Ghofur, 2009). Technoscape adalah tempat dan ruang imajinasi masyarakat dalam memanfaatkan teknologi ke seluruh dunia. Finanscape merupakan sebuah pergerakan luas yang melintasi batas berbagai negara. Terakhir ideoscape lebih kepada pergerakan ideologi politik itu sendiri yang global.

Pergerakan budaya asing yang secara global dapat diakses dengan mudah melalui teknologi oleh masyarakat semakin diadopsi sebagai sebuah literasi informasi baru (Anastasya, 2013). Misalnya, bahasa asing lebih mudah dipelajari dan dipahami dengan adanya tayangan berbahasa asing seperti terdapat dalam film berbahasa Inggris, bahasa Inggris ala Amerika Serikat, bahasa Jepang, Bahasa Korea, Bahasa Mandarin, bahasa India yang mulai digemari oleh masyarakat dan menjadi tren serta mendapat apresiasi tersendiri di kalangan masyarakat pada umumnya. Hanya sayangnya mayoritas masyarakat ibarat menelan mentah-mentah begitu saja dengan istilah gaul selama ini bila mampu menguasai bahasa asing tapi tanpa mereka sadari cenderung meninggalkan bahasa ibunya sehari-hari. Sopiah (2012) mengemukakan bahwa tidak jarang fenomena di mana anak menjawab orang tuanya dengan bahasa asing saat menggerutu disuruh oleh orang tuanya yang sudah tentu tidak dipahami apa yang dikatakan oleh anaknya sehingga menimbulkan misskomunikasi. Tanpa adanya filterisasi akhirnya melemahkan nilai budaya Sunda itu sendiri pada generasi penerus terutama hilangnya keinginan bergotong royong dan sikap ramah terhadap orang lain yang melanda masyarakat generasi muda Sunda.

Generasi muda zaman sekarang atau bahkan populer disebut zaman now tampak tidak terbiasa saat kumpul bersama keluarga besarnya di momentum hari raya atau saat kumpul keluarga di hari tertentu. Sangat kentara sekali generasi muda lebih cenderung menutup diri dan tidak mau bergaul ketika orang tuanya menggunakan bahasa Sunda saat berinteraksi dalam keluarga sehingga cenderung mereka menghindar dan menjawab apa adanya tanpa merasa apa itu termasuk bersikap ramah atau tidak. Mereka tampak tidak biasa dalam mempraktekkan sehari-hari tata nilai keSundaan yang ada dalam lingkungan keluarganya. Menurut Kurnia (2008, hlm. 2) mengemukakan bahwa penting sekali mengintensifkan pengajaran bahasa Sunda kepada anak dengan cara menggunakannya di rumah. Fenomena di lapangan terutama pada orang tua golongan muda usia lebih senang menggunakan bahasa nasional atau bahasa asing dibandingkan mengajarkan bahasa Sunda. 
Pola asuh orang tua berperan sangat penting dalam mewariskan nilai budaya Sunda dalam berinteraksi dengan anaknya (Lickona, 2013). Pola asuh tersebut harus dilakukan saat memberikan perhatian, menanggapi cerita anak, menanggapi keinginan anak, memberikan hadiah, memberikan juga hukuman dan pengaturan lainnya yang harus disisipkan budaya Sunda didalamnya baik secara eksplisit maupun implisit. Berdasarkan fenomena di atas, maka dapat disimpulkan bahwa pola asuh orang tua memiliki peran penting dalam proses pewarisan nilai budaya Sunda pada anak. Dengan memelihara, mendidik, membimbing, dan mendisiplinkan nilai budaya Sunda pada anak secara terus menerus diwajibkan sebagai proses pematangan kedewasaan dalam konteks warisan budaya itu sendiri. Hal tersebut dimaksudkan bukan hanya nilai budaya Sunda dikenal oleh generasi muda tetapi lebih jauh dari itu karakter sosial anak terbentuk sesuai dengan filosofi Sunda.

Orang tua merupakan figur utama bagi anaknya, sebab orang tua cukup banyak berinteraksi dan menjadi pendidik pertama dirumahnya dalam membuat tata aturan yang berlaku dan mengikat sehingga menjadi habit bagi sang anak dalam membentuk karakter sosialnya (Mulyana, dkk., 2019). Selain itu, orang tua memiliki peran penting dalam sistem sosial keluarga di mana menjadi tokoh panutan anaknya selain menjadi pendidik juga menjadi penuntun tata sopan santun. Tentu orang tua mendambakan anaknya memiliki tata kesopanan dan keramahtamahan khas nilai budaya Sunda sehingga mendapat pujian dari orang lain. Berdasarkan ajaran agama bahwa anak adalah amanah dan karunia dari Allah swt sehingga sudah seharusnya orang tua berperan aktif dalam membentuk karakter sosial pada anaknya. Orang tua harus mampu menerapkan akhlak yang baik dan berkualitas sehingga mampu mengisi dan berperan terhadap bangsa, negara dan agamanya.

Pola asuh anak yang dilakukan oleh orang tua tentu mengalami perbedaan satu sama lainnya. Hal tersebut dikarenakan setiap orang tua memiliki metodenya sendiri-sendiri dan perspektif yang berbeda pula. Waridah (2000) mengemukakan bahwa intinya apabila pola asuh orang tua dalam mendidik anaknya dengan budaya Sunda yang benar maka akan memengaruhi perilaku anak itu sendiri. Sementara itu, bila pola asuh orang tua dalam mendidik anaknya menggunakan kata kasar dalam kultur Sunda dan cenderung tidak sopan tentu dapat dipastikan anaknya akan lebih mengenal dan memahami bahkan mengimplementasikan sikap kurang sopan tersebut dalam kehidupan sehari-harinya. Banyak perilaku yang menyimpang pada anak karena kurangnya pendidikan dan pengawasan oleh orang tua sebagai tempat didikan pertama untuk anak.

Pola pengasuhan tidak hanya sebatas mau dan mampu merawat anak saja akan tetapi menanam pula nilai-nilai kebaikan budaya Sunda. Pola asuh itu tidak hanya merawat dan mengawasi anak saja tetapi melipui pendidikan, sopan santun, tanggung jawab, pengetahuan tata cara pergaulan khas orang Sunda dan disiplin kebersihan. Hal tersebut bersumber pada pengetahuan kebudayaan orangtuanya. Karakter menurut Michael Novak (dalam Lickona, 1991 hlm. 81) mengemukakan bahwa campuran kompatibel dari seluruh kebaikan yang diidentifikasi oleh tradisi religius, cerita sastra, kaum bijaksana, dan kumpulan orang berakal sehat yang ada dalam sejarah. Sebagaimana yang dikemukakan oleh Novak, tidak seorang pun yang memiliki semua kebaikan itu, dan setiap orang memiliki beberapa kelemahan. Orang-orang dengan karakter yang sering dipuji bisa jadi sangat berbeda antara satu dengan yang lainnya.

Khan (2010, hlm. 14) mengemukakan bahwa pendidikan karakter merupakan pendidikan yang tidak saja membimbing dan membina setiap anak didik untuk memiliki kompetensi intelektual, kompetensi keterampilan mekanik, tetapi juga harus terfokus kepada pencapaian pembangunan dan perkembangan karakter. Berdasarkan teori tersebut maka manusia terdidik wajib memiliki kompetensi intelektual atau silih asuh dan harus memiliki kompetensi keterampilan mekanik yang dapat diartikan silih asuh. Sementara itu, bila mampu mencapai pembangungan dan karakter maka disebut silih asih. Sudah barang tentu bahwa pendidikan berbasis keluarga menjadi pola utama dan hakiki di mana pendidikan budaya Sunda 
dipraktekkan dalam keluarga menjadi sangat penting dalam mendidik anak-anaknya. Penanaman bahasa Sunda dalam keluarga mutlak harus dilakukan dengan memperhatikan mana penyampaian yang tutur kata halus dan mana yang kasar sehingga tidak boleh diucapkan sembarangan. Bukti nyata seorang individu dia berasal dari Sunda atau buka adalah pada saat nilai budaya Sunda atau bahasa Sunda itu sendiri tercermin dalam habit sehari-hari. Ketika orang Sunda berbicara maka dia sedang membentuk karakter dan orang tersebut sedang mengembangkan pendidikan karakter yang tertanam dari habit dalam keluarganya.

Fokus masalah dalam penelitian dan pengabdian kali ini adalah bagaimana tingkat pemahaman orang tua mengenai nilai budaya Sunda di Desa Sukamanah Kecamatan Cigalontang Kabupaten Tasikmalaya Provinsi Jawa Barat Indonesia. Selain itu, juga ingin mengetahui bagaimana nilai Sunda di desa tersebut dalam konteks pola asuh orang tua dalam membentuk karakter sosial pada anaknya. Hal ini dirasakan sangat penting untuk mengetahui hal awal permasalahan yang terjadi sebelum dilakukan penyuluhan dan pelatihan pola asuh orang tua melalui penanaman karakter sosial nilai budaya Sunda.

\section{METODE}

Metode yang digunakan adalah melalui pendekatan kualitatif dengan mendeskripsikan dan menganalisis situasi sosial yang hasil analisisnya berupa gambaran dalam bentuk uraian naratif (Moleong, 2010). Berdasarkan hal tersebut dapat disimpulkan bahwa suatu penelitian yang mengamati permasalahan sosial yang terjadi dalam masyarakat di mana pada saat mencari informasi data dan peneliti menjadi alat utama, setelah data terkumpul maka disusun secara terperinci dalam bentuk kata-kata atau uraian naratif. Sugiyono (2012) mengemukakan bahwa metode deskriptif diambil dalam penelitian dan pengabdian kali ini dengan maksud menggambarkan situasi kondisi yang sekarang dan yang sudah dilakukan dengan tujuan untuk memecahkan masalah yang ada di masa sekarang. Karena itu, metode deskriptif diambil untuk menjadi fokus penelitian pada Desa Sukamanah Kecamatan Cigalontang Kabupaten Tasikmalaya Provinsi Jawa Barat Indonesia.

Teknik analisis data memberikan makna terhadap data informasi yang didalamnya terdapat proses penelitian yang dilakukan peneliti. Aktiviitas dalam analisis data kualitatif dilakukan secara interaktif dan berlangsung secara terus menerus sampai tuntas, sehingga saat tidak ditemukan kembali infornasi maka dianggap data sudah jenuh (Nazir, 2005). Aktivitas dalam analisis data, seperti reduksi data, data display, dan tahap verifikasi data.

\section{HASIL DAN PEMBAHASAN}

Tingkat pengetahuan orang tua mengenai kebudayaan Sunda di Desa Sukamanah Kecamatan Cigalontang Kabupaten Tasikmalaya Provinsi Jawa Barat berdasarkan hasil penelitian bahwa termasuk dalam kategori yang bagus. Hal tersebut tercermin dalam pengetahuan budaya Sunda yang mana orang tua sudah menerapkan dan memberikan pelajaran warisan nenek moyangnya kepada generasi penerusnya yaitu anak. Orang tua selalu berupaya menanamkan warisan budaya Sunda kepada anaknya dalam kehidupan sehari-hari seperti menerapkan dan memberikan pembelajaran kepada anak-anak untuk bisa mempelajari dan memahami budaya Sunda itu sendiri. Namun, mereka kesulitan untuk menerapkannya dikala anak-anaknya lebih asyik mengenal dunia internet yang sedang berlangsung. Supanto (1990) mengemukakan bahwa tak jarang pola pemikiran anak cenderung hedonis dan kasar terhadap orang tuanya. Kebanyakan orang tua menyerah dengan keadaan tersebut dan akhirnya umpatan kata kasar dalam bahasa Sunda keluar dari mulut orang tuanya. Hal tersebut menjadi pewarisan budaya yang tidka baik di mana ketika anaknya beranjak dewasa dan menikah maka pola mendidik anaknya jauh dari kultur nilai budaya Sunda yang diajarkan leluhurnya. Berkata dan bersikap kasar cenderung ditunjukkan pada orang tua muda dan mereka enggan menggunakan 
bahasa Sunda dalam kesehariannya dan dianggap kuno. Mereka baru berbicara Sunda kala memarahi anaknya dan dengan bahasa yang kasar dan sikap yang tidak mencerminkan sikap orang Sunda sejatinya yang siluih asah silih asih silih asuh. Orang tua yang berbudaya Sunda menjadi sangat penting perannya dalam membentuk karakter sosial anak-anaknya. Orang tua di desa tersebut sangat antusias dan menganggap sangat penting mendidik budaya Sunda pada anaknya sejak dini.

Saat penyuluhan dan pelatihan dilakukan maka terlihat antuasias dan motivasi kembali dari para orang tua untuk kembali menanamkan warisan nenek moyang dengan nilai budaya Sunda. Mereka menyadari pentingnya nilai budaya Sunda dalam membentuk karakter sosial pada anaknya dengan asumsi kekhawatiran selama ini mengenai efek negatif yang tidak tersaring oleh orangtunya. Pelatihan pola orang tua asuh ini mengajarkan kembali peran penting orang tua dalam mendidik anak dengan nilai budaya Sunda. Metode tersebut tertuang dengan memberikan pelatihan kembali pola asuh orang tua dengan nilai-nilai Sunda. Orang tua wajib memberikan pengetahuan kepada anak dengan memberikan nilai-nilai budaya Sunda yang harus diaplikasikan dalam kehidupan sehari-hari. Bahkan istilah pamali diajarkan kembali untuk memberikan peringatan dini tentang apa yang tidak boleh dilakukan. Hal tersebut dianggap sangat efektif karena dapat menjadi filterisasi anak saat bertindak sehingga tidak gegabah dalam bertutur kata, bersikap dan berperilaku (Kurnia, 2008). Ayah dan ibu berperan aktif dalam memberikan contoh kepada anak-anak untuk menjadi terbiasa dengan ilmu pengetahuan sosial yang diajarkan. Tingkat ilmu pengetahuan sosial pada orang tua memang sudah melekat sebagai pewarisan budaya Sunda dari ayah ibu sebelumnya di mana mereka dididik sejak kecil terbiasa bertutur kata halus berbahasa Sunda, tata krama khas Sunda, dan menunjukkan karakter sosial orang Sunda asli. Hal inilah yang pada akhirnya menjadi modal sosial orang tua dalam mendidik anaknya sebagai bagian dari pengembangan keterampilan sosial.

Metode orang tua dalam memberikan ilmu pengetahuan sosial mengenai nilai budaya Sunda terhadap anak dengan memberikan sikap yang mengayomi sebagai identitas kultur Sunda. Orang tua merupakan figur penting yang utama bagi anak untuk sosialisasi karakter sosial anak khas Sunda itu seperti apa dan bagaimana. Sebab orang tua adalah orang yang berpengalaman dengan karakter sosial budaya Sunda yang wajib diwariskan secara turun temurun kepada generasinya. Orang tua banyak memberikan sosialisasi pada anaknya dalam aturan, nilai dan habit yang disertai sikap hidup orang Sunda.

Langkah-langkah dan proses penanaman nilai budaya Sunda oleh orang tua pada pembentukan karakter sosial anaknya di Desa Sukamanah adalah dengan cara membentuk karakter anak yang nyunda dan diterapkan dalam kehidupan sehari-hari sebagai pengamalan nilai budaya itu sendiri. Penekanan dilakukan oleh orang tua terhadap anaknya ketika mereka bermain atau keluar rumah untuk berinteraksi dengan orang lain (Koentjaraningrat, 1985). Mereka harus membawa nilai budaya Sunda yang tercermin dalam sikap dan perilakunya. Anak-anak dituntut untuk menyampaikan literasi informasi budaya Sunda dengan memiliki rasa malu apabila melanggar nilai-nilai tersebut. Orang tua berpesan kepada anaknya untuk selalu menaati aturan nilai-nilai budaya Sunda dan melakukan penegasan bilamana anaknya melakukan pelanggaran yang tidak sesuai dengan nilai yang berlaku. Orang tua menjadi filter pertama dalam menganalisis perubahan sikap dan perilaku anaknya bilamana terjadi penyimpangan yang tidak sesuai ajaran nilai budaya Sunda. Orang tua mencoba terus menerus memantau anaknya dari pengaruh negatif arus globalisasi yang semakin tak terbendung dan semakin sulit membedakan mana yang baik dan yang buruk (Mulyana, 2019). Filter yang dilakukan orang tua akan sangat bermanfaat bagi anaknya untuk menyaring budaya asing mana yang tidak ditiru dan mana yang dapat ditiru bahkan dikolaborasikan walaupun tetap dengan nilai dan norma yang berlaku. Pemilahan tersebut akan semakin baik dalam polanya ketika orang tua berperan memberikan asumsinya saat berkumpul dalam momentum kebersamaan 
keluarga di mana ayah atau ibu menyampaikan baik buruknya efek globalisasi sehingga anak bisa menyimpulkan mana yang diserap dan mana yang tidak.

Orang tua pun memberikan penanaman nilai budaya Sunda dalam kesehariannya, jadi jangan sampai orang tua malah berperilaku kebarat-baratan dan tidak menunjukkan ciri orang Sunda itu sendiri. Bahkan tidak hanya anak-anak mereka bahkan masyarakat pun memiliki peran dan terlibat dalam menanamkan karakter sosial pada anak melalui nilai budaya Sunda. Orang tua di desa Sukamanah pun mengajarkan kesenian pada anak-anaknya dengan alat-alat musik tradisional khas Sunda sebagai penanaman rasa cinta dan bangga terhadap kesenian daerahnya. Karinding menjadi alat kesenian yang banyak diajarkan oleh orang tua kepada anaknya. Karinding merupakan salah satu alat musik yang ditinggalkan leluhur untuk orang Sunda dan biasanya digunakaan saat mengusir hama di area pesawahan. Alat musik ini diperkenalkan sejak dini supaya mereka mengenal dan mau menggunakan alat tersebut dalam hiburan kesehariannya selain memiliki fungsi pengusir hama.

Nilai-nilai budaya Sunda yang menjadi ciri khas dan tercermin dalam pameo silih asah, silih asih, silih asuh memiliki makna mengasihi, saling memperbaiki, dan saling melindungi. Konsep tersebut mencoba kembali ditanamkan pada masyarakat Desa Sukamanah di mana mereka wajib saling bertegur sapa, saling bergotong royong kerja bakti, bahkan ketika ada yang memperbaiki rumah mereka bersama tanpa diminta dan dengan sukarela membantu menyelesaikan perbaikan rumah tetangganya. Mereka pun wajib berkirim makanan ketika memiliki rejeki lebih dan dibagikan ke tetangga terdekat dan hal ini semakin mempererat tali persaudaraan di antara mereka bahkan tidak memiliki ikatan darah pun akhirnya diakui sebagai saudara. Selain itu, wajib saling melindungi dari ancaman manapun tampak terlihat baik kala ada yang berduka mereka akan bahu membahu berteriak meminta tolong dan segera warga berhamburan datang serta secara sukarela langsung membantu tanpa diminta. Orang tua berupaya semaksimal mungkin mendidik anaknya untuk mewarisi nilai budaya Sunda tersebut sebagai penanaman karakter sosial. Sementara itu, pengembangan keterampilan sosial untuk anaknya, maka orang tua harus mengupayakan agar anaknya melanjutkan sekolah ke jenjang yang lebih tinggi agar memiliki kompetensi yang dibutuhkan dalam bekerja nantinya. Peran Pemerintah Desa pun sangat penting memfasilitasi hal ini untuk dapat membantu masyarakatnya yang membutuhkan bantuan biaya sekolah anaknya.

Sikap kakak menyayangi adik dan adik menghormati kakak pun harus diajarkan sedini mungkin oleh orang tua dengan baik, dan ada rasa malu ketika berbuat kesalahan. Orang tua harus berbicara bahasa Sunda yang halus dan bersikap lemah lembut terhadap anaknya dengan membawa pesan bahwa Sunda adalah budaya yang indah dan tidak perlu malu mengaku sebagai orang Sunda. Dalam prosesnya orang tua mengajarkan budaya Sunda yang santun kala bertemu dengan orang lain dan menghormati tamu jauh yang datang ke rumah. Hal tersebut menjadi pembelajaran yang sangat baik bagi anaknya dalam memfilterisasi pengaruh negatif arus globalisasi. Anak yang santun pun wajib mendapat pujian orang tuanya dan ditanamkan nilainilai budaya Sunda yang selalu berterimakasih kala ada orang yang memujinya sambil memperlihatkan gestur tubuh dan mimik muka yang ramah. Orang tua tidak boleh malu menjadi orang Sunda yang Nyunda.

Orang tua menjadi penyaring dari pengaruh buruk akibat globalisasi dan seutuhnya berperan terhadap anaknya dalam memilah mana yang tepat dikonsumsi oleh anaknya. Orang tua wajib memberikan penanaman nilai budaya Sunda dalam keseharian dengan mengajak pula lingkungan masyarakat untuk kembali meneruskan kultur budaya sunda yang someah hade ka semah. Hal ini sangat penting untuk selalu terus diwariskan kepada anaknya sebagai generasi penerus sehingga tercermin karakter sosial jatidiri Sunda. Keberhasilan orang tua dalam membentuk karakter sosial anak yang Nyunda akan sangat penting karena proses pelestarian budaya leluhur menjadi berproses dan akan terus berkala. Bila semakin menjadi habit maka tidak menjadi kekhawatiran saat proses negatif dari luar masuk karena sudah memiliki 
polarisasi penangkal dalam kultur budaya Sunda yang sudah mengakar karakternya pada generasi penerus (Ekajati, 1993).

Orang tua harus terus memberikan aturan, nilai dan kebiasaan serta sikap hidup dalam kesehariannya. Pembentukan karakter sosial pada anak tergantung bagaimana konsep yang diterapkan dalam rumah tangga orang tua yang menjadi suri tauladan bagi anaknya. Metode pendidikan berakhlak mulia, berkualitas, kompeten, dan yang paling penting karakter Nyunda harus terus lestari. Orang tua harus mengharapkan anaknya menjadi generasi-generasi yang tangguh dan tidak malu menjunjung tinggi nilai-nilai kebudayaan Sunda dalam kesehariannya. Tetep (2018) mengemukakan bahwa sikap orang tua dalam membentuk karakter nilai-nilai budaya Sunda senantiasa dicontohkan meliputi nilai-nilai agama, nilai-nilai sopan santun, tata krama, dan nilai-nilai keSundaan dalam pameo silih asah, silih asih, silih asuh yang harus terus ditanamkan.

Berdasarkan hasil penelitian dan pengabdian ini maka dapat diambil hikmahnya bahwa nilai-nilai yang tercermin dalam keseharian dari aktivitas keluarga memiliki peranan yang sangat penting dalam pewarisan budaya Sunda. Sikap saling menyayangi, saling tolong menolong, gotong royong minimal di dalam keluarga harus selalu dilestarikan. Hal tersebut sangat berguna kala luaran pencapaiannya diaplikasikan dalam lingkungan sekitar. Tentu akan sangat bermanfaat nantinya bagi masyarakat sekitar itu sendiri. Sikap melindungi terhadap keluarga harus diwujudkan dari pengaruh negatif luar yang semakin merajalela. Bila tidak diantisipasi bukan sebuah keniscayaan kultur budaya Sunda hanya menjadi dongengan orang tua semata.

\section{KESIMPULAN DAN SARAN}

Berdasarkan hasil penelitian dan pengabdian di Desa Sukamanah Kecamatan Cigalontang Kabupaten Tasikmalaya Provinsi Jawa Barat, maka ditarik kesimpulan bahwa peran pembentukan karakter sosial anak melalui nilai-nilai budaya Sunda dalam pola asuh orang menjadi sangat penting dilakukan sebagai bentuk kebiasaan dan sesuai dengan pameo khas jatidiri Sunda, yaitu silih asah, silih asih dan silih asuh. Tingkat pengetahuan orang tua mengenai kebudayaan Sunda di desa tersebut cukup bagus hanya mereka memang memiliki kendala saat anaknya terpengaruh efek negatif globalisasi sehingga acuh tak acuh. Biasanya orang tua langsung marah dan membentak anak tersebut dan tidak jarang malah memicu pertengkaran anak dan orang tua yang tentu tidak seharusnya terjadi. Karena itu, pola asuh dengan nilai budaya Sunda dan pameo yang selama ini dikenal sangat penting untuk kembali diterapkan di desa tersebut. Tidaklah terlalu sulit dikarenakan mereka mayoritas berbahasa Sunda dan asli penduduk tersebut. Generasi tua pun masih ada dan bisa menjadi jembatan penghubung idealnya karakter sosial khas bernilai budaya Sunda seperti apa diajarkan. Peneliti memberikan penyuluhan dan pelatihan dengan tanpa kesan menggurui tetapi berangkat dari kebutuhan dan analisa lingkungan sekitar. Setelah memetakan permasalahan mereka sebenarnya peneliti lebih ke arah mengingatkan kembali warisan budaya leluhurnya dan hal tersebut disambut antusias. Pola yang baik dapat diterapkan pada orang tua yang masih kategori muda dan anak-anaknya masih kecil di mana mereka harus memunculkan keSundaan dalam diri anaknya. Orang tua berusia muda tidak ragu dan malu dianggap ketinggalan zaman dengan berbicara bahasa Sunda.

Berkaitan fenomena di atas, maka peneliti lebih menyoroti kepada peran pemerintah daerah untuk senantiasa melestarikan kekhasan Sunda di daerahnya. Ini sangat penting mengingat domisili desa tersebut di Jawa Barat yang mana menjadi identitas keSundaan. Literasi informasi menggunakan bahasa asing dan nasional selama ini bisa ditambah dengan bahasa Sunda yang akan menambah wawasan masyarakatnya terutama generasi muda. Bagi orang tua tentu mereka pendidik utama di rumahnya dan tetap mengontrol anaknya agar karakter sosial mereka terjaga dengan baik dan benar-benar mencerminkan nilai budaya Sunda. Selain itu, dalam dunia 
pendidikan bahwa bahasa daerah tetap dirasakan sangat penting agar peserta didik semakin mengenal idealnya bahasa ibunya seperti apa yang benar, kemudian sikap dan perilaku seperti apa yang harus ditunjukkan dalam kehidupan sehari-hari. Semoga peneliti dan pengabdian selanjutnya akan lebih mengembangkan ke arah yang lebih luas dengan falsafah-falsafah Sunda yang lebih kental sehingga menghasilkan bobot yang lebih bermutu lagi dan lebih komprehensif/

\section{REFERENSI}

[1] Anastasya, M. (2011). Globalisasi dan kawaiiguzzu : analisis teori Globalisasi appadurai dalam studi kasus karakter Hello Kitty. (SKRIPSI). Fakultas Ilmu Pengetahuan Budaya. Universitas Indonesia. Depok

[2] Ekadjati, E. (1993). Kebudayaan Sunda. Suatu Pendekatan Sejarah Jilid I. Jakarta : Pustaka Jaya.

[3] Ghofur, Abdul, dkk. (2009). Edukatif Blog. Pengaruh Pola Asuh Orang Tua Terhadap Perkembangan Anak.

[4] J. D. Narwoko dan Suyanto, B. (2007). Sosiologi: Teks Pengantar dan Terapan. Jakarta: Kencana. Edisi 2, Cetakan ketiga. 2007. hal. 57 [10 Oktober 2016]

[5] Koentjraningrat, (1985). Kebudayaan, Mentalitet, dan Pembanggunan. Jakarta : P.T. Gramedia.

[6]Kurnia. A. (2008). Pewarisan Budaya Sunda. Tersedia:http://malamtadi.wordpress.com/pewarisa n_budaya_sunda/Wahyudin, D. (2010). Budaya Sunda ditengah Modernisasi dan Postmodernisasi.Tersedia:http://dedenmyger.blogspot.com/2010/12/budaya_sunda_diten gah_modernisasi_dan_postmodernisasi

[7] Lickona, T. (2013). Mendidik untuk Membentuk Karakter: Bagaimana Sekolah dapat Memberikan Pendidikan Tentang Sikap Hormat dan Bertanggung Jawab. Jakarta: Bumi Aksara.

[8] Moleong, J.X. (2010). Metodologi Penelitian Kualitatif. Jakarta: Departemen Pendidikan dan Kebudayaan.

[9] Mulyana, E., Tetep, Widyanti, T. (2018). Social Studies Learning Strategy to Develop Cultural Intelligence in The 21st Century Through Controversial Issues and Problem Based Introduction. Promoting The 21st Century Skills in Social Studies Learning. In: The 3rd International Seminar on Social Studies and History Education (ISSSHE). http://repository.upi.edu/34125/19/SPS_P,

[10] Mulyana, E, dkk. (2019). Dampak Literasi Informasi Terhadap Kepedulian masyarakat Kabupaten Garut Dalam Menghadapi Ancaman Bencana Longsor. Prosiding Seminar Nasional Pendidikan Geografi “Kontribusi Pendidikan Geografi Di Era Revolusi 4". ISBN: 978-623-92801-0-9.

[11]Mulyana, E. (2019). Upaya Pemberdayaan Ekonomi, Sosial dan Budaya pada Masyarakat Melalui Pengembangan Bisnis Ekowisata. Business Innovation and Entrepreneurship Journal 1 (1), 38-43.

[12] Nazir, M. (2005). Metode Penelitian. Bogor: Ghalia Indonesia.

[13] Sofiah, Rostiasih, S, H (2012). Pola Komunikasi Keluarga Dalam Mengenalkan dan Menanamkan Nilai Budaya Kepada Anak. Dalam Jurnal Program Studi Ilmu Komunikasi, Universitas Sebelas Maret Surakarta [Online]. Tersedia : http://www.jurnalkommas.com/docs/JURNAL\%2 0KOMUNIKASI.\%20HAFIZAH\%20SIDI\%20R. \%20(D1212037).pdf $\quad[10$ Oktober 2016].

[14] Sugiyono, (2012). Metode Penelitian Kuantitatif, Kualitatif, dan R\&D. Bandung : Alfabeta 
[15] Supanto, et al. (1990). Pola Pengasuhan Anak Secara Tradisional Daerah Istimewa Yogyakarta. Jakarta: Departemen Pendidikan dan Kebudayaan.

[16] Tetep. (2018). Reorientation of Values of The Indonesian Diversity (Ke-Bhineka-an Indonesia) to Reaffirming the National Identity. Annual Civic Education Conference (ACEC 2018).

[17] Waridah, S.Q, dkk. (2000). Antropologi untuk SMU Kelas 3 Sesuai Kurikulum GBPP 1994. akarta : Bumi Aksara.

[18] Widyanti, t., Tetep, Mulyana. E (2019). Analisis Faktor Pendidikan dan Demografi terhadap Tingkat Literasi Ekonomi Mahasiswa. Business Innovation and Entrepreneurship Journal. 